\title{
LA COLECCIÓN DE NIÑOS JESÚS DEL ESCULTOR CRISTÓBAL RAMOS DEL MONASTERIO DE SAN LEANDRO DE SEVILLA
}

\author{
THE COLLECTION OF CHILDS JESUS \\ BY THE SCULPTOR CRISTÓBAL RAMOS \\ OF THE MONASTERY OF SAN LEANDRO OF SEVILLE
}

\author{
SAlvador Guijo Pérez \\ Grupo de investigación HUM686: Centro de estudios e investigación de la religiosidad \\ andaluza (CEIRA). España \\ ORCID: 0000-0002-3768-8430 \\ salvadorguijo@hotmail.com
}

Se presentan siete piezas inéditas del escultor sevillano Cristóbal Ramos (1725-1799) conservadas en el monasterio de San Leandro de Sevilla. Destacan las iconografías del Sagrado Corazón de Jesús Niño y el Divino Pastor. El análisis del medio que rodea a estas imágenes revelan los rasgos que remiten claramente a sintagmas tradicionales barrocos, así como a la producción del artista propuesto.

Palabras clave: escultura; Cristóbal Ramos; Sevilla; monasterio de San Leandro; Niño Jesús.

We present seven unpublished pieces by the Sevillian sculptor Cristóbal Ramos (1725-1799), preserved at the Monastery of San Leandro in Seville. The iconographies of the Sacred Heart of Child Jesus and the Divine Shepherd stand out. The analysis of the environment that surrounds these images reveals the traits that clearly refer to traditional Baroque phrases, as well as to the production of the proposed artist.

Keywords: sculpture; Cristóbal Ramos; Seville; Monastery of San Leandro; Child Jesus. 


\section{INTRODUCCIÓN}

Con el presente artículo presentamos siete piezas del escultor sevillano Cristóbal Ramos (1725-1799) conservadas en el monasterio de San Leandro de Sevi$1 a^{1}$. No conocemos la fecha exacta de la fundación de este agustino convento ${ }^{2}$, sin embargo, parece ser que ya existía hacia el año 1260 cuando aparece citado entre las mandas de un testamento que recogió Ortiz de Zúñiga ${ }^{3}$. Igualmente, documentos del archivo monacal relatan la existencia de este poco después de la conquista de Sevilla ${ }^{4}$. Así lo recogen cronistas e historiadores ${ }^{5}$, que catalogan a San Leandro como monasterio de fundación fernandina ${ }^{6}$ y anterior al siglo XIV. El monasterio sufrió en sus inicios el traslado de su emplazamiento hasta en tres ocasiones. Respecto al lugar que ocupa actualmente, recoge el Protocolo del convento la donación que escasos dos meses antes de su fallecimiento, pues murió el 23 de marzo de $1369^{7}$, concedió a la comunidad de San Leandro el rey Pedro I. Se trata de las casas en las que a día de hoy continúa teniéndolas en propiedad desde el 19 de enero de $1369^{8}$.

Entre el patrimonio artístico de este monasterio 9 se encuentran multitud de imágenes del Niño Jesús con sus distintos apelativos y advocaciones. La proveniencia de las mismas nos resulta desconocida desde el archivo monacal pero, como

${ }^{1}$ Llordén, 1973. Guijo Pérez, 2017; 2018 a.

2 Miura Andrades, 1999: 145.

3 Ortiz de Zúñiga, 1796: 236. "Subsistían ya también en toda forma los Conventos de San Pablo, San Francisco, la Merced, la Trinidad y San Leandro: para todos y para su obra hay legados píos en un testamento de este año (1260); al de San Leandro, que es su primer memoria, dice para los Cofrades de San Leandro; é á las devotas Monjas que allí moran: vese que había ya Cofradía y morada de mujeres Religiosas con título de San Leandro...".

${ }^{4}$ Archivo del monasterio de San Leandro (AMSL), Memoria y Tradición de la venida de la milagrosa Imagen de María Santísima con el Amabilísimo título de las Virtudes, y milagros que la Señora ha obrado por mediación de esta hermosísima y devota Imagen. Sevilla, 1 de octubre de 1817, ms. Anotaciones en diferentes libros de cuentas de diferentes siglos, ms., y otros legajos del archivo conventual donde se recogen los orígenes del mismo, ms.

${ }_{5}^{5}$ En lo referente a Fernando III consúltese: González González, 1986. Martínez Díez, 1993. González Jiménez, 2006.

${ }^{6}$ Arana de Varflora, 1789: 57. Ortiz de Zúñiga, 1796: 236. González de León, 1839: 82-84; 1844: 85-87. De Madrazo, 1884: 601. Gestoso, 1889: 261. Confróntese también la sección especial del Archivo Municipal de Sevilla, que comprende los papeles y documentos adquiridos por el Excmo. Ayuntamiento de la testamentaría del Sr. Conde del Águila. Comunidades religiosas. Convento de monjas de San Leandro, tomo I, número 15, hay dos relaciones, ms.

7 Díaz Martín, 1995: 369.

8 AMSL, Libro de Protocolo del monasterio de San Leandro, 1666, cuad. 1, f. 4v. Privilegio. Pedro I. 19 de enero de 1369, ms.

${ }^{9}$ En la retablística de su iglesia confróntese Guijo Pérez, 2018b; 2019 b. 
bien indican testimonios expertos, podría estar en el pago de la dote de una postulante, en una dádiva a la comunidad o podría haber pertenecido a alguna de las seglares, damas de noble linaje o de acompañamiento que sin profesar en la Orden vivían en el cenobio ${ }^{10}$. Nos decantamos por la primera opción como la más generalizada; igualmente, queremos hacer hincapié en la especial importancia que estas imágenes infantiles y pueriles de Cristo tuvieron en la vida conventual ${ }^{11}$. Las mismas estaban presentes de forma cotidiana en las celdas de las religiosas y en las principales estancias de la clausura, alcanzando una mayor relevancia en los tiempos litúrgicos de Navidad y Semana Santa ${ }^{12}$ o en las fiestas de la Sagrada Familia y del Dulce Nombre. Nos encontramos ante esculturas de meditación desde la intimidad de la religiosa y objeto de piadosas reflexiones. Sin embargo, en muchas ocasiones se ha relacionado la devoción de estos Niños y sus cuidados, exclusivamente, con la afectividad femenina de las clausuras. Es cierto que las religiosas que tenían la custodia o el cargo de camarera de alguna de estas imágenes las vestían e incluso llevaban en procesión. Pero "esa ternura maternal envuelta de religiosidad no es realmente el motivo por el que estas imágenes proliferaron y fueron colmadas de atenciones y ornatos en nuestros conventos"13. La doctora Leticia Arbeteta rehúsa este planteamiento de madres frustradas ya que implica un profundo desconocimiento de la esencia de la vida contemplativa, pues el culto de estos niños forma parte de un conjunto de tradiciones basadas en la liturgia cristiana y en la piedad intimista ${ }^{14}$. Es precisamente en los conventos donde la devoción de estos niños se ha mantenido prácticamente intacta ${ }^{15}$. La relación que se les tenía a estas imágenes en la comunidad de San Leandro era casi familiar donde tenían apelaciones propias conforme a sus características: curita, bobito, pastorcito, dormidito, de la paz... o a sus acciones: el quitapesares, el milagroso, el porterito... Así mismo existían aquellos que tenían una función propia: los expósitos, espositos o Niños de los votos que portaban las monjas el día de su profesión, o los limosneros, por ejemplo. Dependiendo del convento estos sobrenombres cambiarían conforme a las circunstancias y al celo devocional de cada comunidad. Debemos, igualmente, hacer resaltar estas piezas y sus iconografías desde un punto de vista artístico aplicándoles estudios basados en los principios de la antropología del arte, superando posicionamientos que minusvaloran este tipo de piezas como fruto del arte popular o femenino de una manera despreciativa.

\footnotetext{
10 Peña Martín, 2010: 114.

${ }_{11}$ Llompart i Moragues, 1980: 368-371.

12 Peña Martín, 2009: 28.

13 Bartolomé García, 2015: 201.

14 Arbeteta Mira/Fernández Collado, 2002: 24. Como obras dedicadas a la imagen del Niño Jesús en la clausura deben consultarse entre otras: Arbeteta Mira, 1996. Arbeteta Mira/Fernández Collado, 2003. Dobado Fernández, 2010. Peña Martín, 2011.

15 Bartolomé García, 2015: 201.
} 
Las imágenes del Niño Jesús que aportamos en este estudio son esculturas en terracota policromada, fechables en la segunda mitad del siglo XVIII dentro del periodo de producción del escultor Cristóbal Ramos Tello (1725-1799). La trayectoria artística del escultor se encuadra en la etapa final del Barroco de la escuela sevillana. Fue un destacado miembro de la comunidad artística hispalense de la segunda mitad del siglo XVIII, siendo teniente de escultura de la renombrada Real Escuela de las Tres Nobles Artes de Sevilla. La misma fue continuadora de la que fundaran, el 1 de enero de 1660, Bartolomé Esteban Murillo y Sebastián de Llanos y Valdés, entre otros insignes pintores y artistas. Sus labores docentes academicistas fueron compaginadas exquisitamente con la práctica de la imaginería. Su predilección por el modelado y el uso de la terracota en vez de la madera en sus obras le hicieron ganar el apelativo de "escultor en barro". Sus trabajos se solían complementar con el uso de telas encoladas dotando de dinamismo a los ropajes de las imágenes representadas. La preferencia del artista por el pequeño formato y sus hondas raíces tradicionales e, incluso, de cierto toque popular explicó el gran éxito que alcanzarían sus trabajos orientados a una devoción que se transformó en doméstica ${ }^{16}$. Por medio de este artículo damos a conocer siete piezas inéditas de Niños Jesús que se suman al amplio catálogo de obras del autor. Se trata de esculturas de carácter religioso que se le pueden atribuir al escultor por sus estrechas similitudes con otras documentadas o firmadas. Todas se conservan en diferentes estancias del monasterio de San Leandro de Sevilla, tal y como lo exponemos a continuación.

\section{EL SAGRADO CORAZÓN DE JESÚS NIÑO, "EXPÓSITO O ESPOSITO”}

El culto al Sagrado Corazón de Jesús tiene una fuerte vinculación devocional con la historia del monasterio siendo este de los pioneros de su propagación en Sevilla ${ }^{17}$. La escultura que representa este misterio actualmente se halla en la sala capitular, mide 25 centímetros de alto y reposa sobre un pequeño escabel con forma de nube, tachonada por tres cabezas aladas de querubes de siete centímetros de alto. Ambos elementos forman una única pieza (Figura 1). Se trata de una obra de terracota policromada de pequeño formato, con acabado minucioso y realista de las cabezas, similar tratamiento de los paños y cierta afectación en la gesticulación de las manos. La imagen principal se encuentra erguida con una actitud dinámica descargando el peso sobre la pierna izquierda, al mismo tiempo que la derecha se encuentra ligeramente levantada y retrasada en una pequeña protuberancia de la nube. La anatomía infantil se muestra cubierta por vestiduras de telas encoladas que apenas dejan ver sus miembros. El Niño Jesús viste túnica

\footnotetext{
16 Sobre Cristóbal Ramos confróntese la obra de Montesinos Montesinos, 1986.

${ }^{17}$ Guijo Pérez, 2019a: 496.
} 
con sobremanto marrón anudado con una lazada dorada a la cintura similar a los de otras colecciones ${ }^{18}$. Los tonos claros con tonos mates a la hora de aplicar la policromía hacen que las obras infantiles de Ramos tengan una gracia especial, una belleza idealizada a medio entre el gusto rococó y el academicismo pujante a fines del siglo XVIII. Este representa los estigmas de la pasión en las manos y en los pies. Resulta significativa su herida en el pecho de la cual extrae su corazón con la mano diestra ligeramente recogida hacia él ${ }^{19}$. El brazo izquierdo se extiende hacia el frente en actitud de donación manteniendo la mirada fija hacia el fiel. El rostro es muy característico del autor: posee cejas arqueadas, ojos de cristal que carecen de pestañas postizas, nariz corta y boca abierta que deja al descubierto la hilera superior de dientes. Se trabajó su cabellera minuciosamente con ensortijados bucles que no cubren sus orejas, siendo coronado por una diadema con forma de resplandor de plata dorada. La imagen se encuentra oscurecida fruto de la suciedad acumulada, asimismo existen pequeñas lagunas en la policromía, así como la pérdida de todas las falanges de la mano izquierda. Toda la composición se asienta sobre una peana de madera dorada de 20 centímetros de altura.

\section{EL BUEN PASTOR NIÑO O "PASTORCITO"}

La escultura que nos ocupa se trata de un Niño Jesús de pie de 35 centímetros realizado en terracota policromada y telas encoladas. Se trata de un tierno y hermoso Niño Jesús situado sobre un monjil risco, cuyo cayado y pieles lo dan a conocer como pastor amante de su rebaño (Figura 2$)^{20}$. La grey es representada por tres corderos, que fijan sus miradas en él y le adoran inclinando sus cabezas para besar las sandalias de sus pies. Según Carmen Montesinos, este divino pastor presenta todos los rasgos comunes a las figuras infantiles y femeninas de la obra del escultor Cristóbal Ramos. Las ondulaciones de sus cabellos están recogidas con

${ }^{18}$ Véase el Niño portado por San José de la colección Marroco, Martínez Lara/Torre Amerighi, 2017: 59, así como el Sagrado Corazón de Jesús Niño de la colección Hermanas Domínguez Arroyo, Reyes de la Carrera, 2014: 216-220.

${ }^{19}$ Guarda parecido con el Niño Jesús sedente en entrega de su corazón del museo del monasterio de Santa Paula de Sevilla, donde el autor realizó una gran colección de obras, así como en sus rasgos con el Niño del San José de la capilla de la Santa Cruz del Rodeo. Véase Montesinos Montesinos, 1986: 40, 46-47 y 69.

${ }^{20} \mathrm{La}$ base documental que fundamenta esta iconografía se encuentra en las propias palabras de Jesús, pues según San Juan, declaró “yo soy el buen pastor” (Juan 10, 11-18), así como en una de las parábolas que narran San Lucas y San Mateo (Lucas 15, 4-7; Mateo 18, 12-14), la cual enlaza, a su vez, con profecías del Antiguo Testamento. Concretamente, las referencias que equiparan al Mesías con el pastor de un rebaño se localizan en los libros de Isaías y Ezequiel y en el salmo 23 (Isaías 16, 1; Isaías 40, 11: "Como un pastor apacienta a su rebaño, en brazo recoge a los corderos, en su seno los lleva"; y Ezequiel 34). Véase Pérez López, 2017: 317. 
bucles hacia la parte posterior a la altura de los pabellones auditivos, dejándolos en su mayor parte despejados (Figura 3). Las cejas se marcan pinceladas de manera muy fina y bastante arqueadas, las pestañas se encuentran pintadas y los ojos son de cristal. La nariz es recta y pequeña, así como la boca que aparece entreabierta y esbozando una leve sonrisa que deja ver la hilera superior de sus dientes. Los cachetes abultados y sonrosados, proporcionados junto a la barbilla que muestra el característico hoyuelo y una ligera papada. De la misma manera, la túnica celeste con adornos dorados siempre se halla recogida en la cintura con un lazo y presenta un gran movimiento en la parte inferior. Sobre la misma porta un pellico o zamarra de corte irregular, propio del mundo pastoril, estofado en oro y de armiño que realza la realeza del que Juan llamara "Rey de reyes y Señor de señores" 21 . En sus pies se observan unas finas tiras doradas a modo de sandalias. La imagen principal se encuentra erguida con una actitud dinámica descargando nuevamente el peso sobre la pierna izquierda, al mismo tiempo que la derecha se encuentra ligeramente levantada y retrasada en lo abrupto del risco. La posición de su mano diestra se encuentra extendida y en actitud de bendecir, mientras que con la mano del brazo izquierdo sostiene el cayado pastoril que representa su cetro.

\section{EL BUEN PASTOR DEL SAGRADO CORAZÓN DE JESÚS NIÑO O "DIVINO PASTOR"}

Esta imagen que actualmente se encuentra en el coro alto, se dispone dentro de una vitrina de madera rematada en crestería y pináculos. Representa al Divino Pastor que porta a sus ovejas (Figura 4). Mide 30 centímetros de alto. Se coloca sobre un monte florido sin pedestal, sobre el que se asienta la figura, de 44 por 28 centímetros. En la fisonomía de esta imagen destaca su corpulencia anatómica, dando aspecto de niño rollizo, con brazos y piernas fornidas. Las facciones del rostro son redondeadas, con ojos de cristal, finas cejas arqueadas y pestañas levemente pinceladas. La nariz es recta y pequeña, así como la boca que aparece cerrada, de labios finos y esbozando una leve sonrisa. Los cachetes abultados y sonrosados resaltan el tratamiento nacarado de la tez. La barbilla muestra el característico hoyuelo de Ramos y se modela una ligera papada. Su cabello, de acusado claroscuro, muestra un modelado minucioso en sus rizos y bucles, que se encrespan y caen justo en el centro de la frente, así como por encima de las orejas. La actitud dinámica del niño, singular por el posicionamiento asimétrico de las extremidades, extiende el brazo diestro separado del cuerpo y portando el cayado pastoril. Al mismo tiempo, recoge el brazo izquierdo junto al pecho, abriendo con su mano el cuello de la túnica que deja ver su Sagrado Corazón flameante, mientras sostiene la cruz de la Redención. Sobre su hombro zurdo porta una oveja,

${ }^{21}$ Apocalipsis 19, 16.

LABORATORIO DE ARTE 32 (2020), pp. 293-312, ISSN 1130-5762

e-ISSN 2253-8305 - DOI http://dx.doi.org/10.12795/LA.2020.i32.15 
característica de la iconografía del "Buen Pastor", a sus pies otras dos lo adoran y contemplan fijamente. El Infante viste una amplia túnica azul, con decoración en motivos dorados, sobre todo, en los ribetes del cuello y las mangas del vestido, tan característica de la producción del autor ${ }^{22}$. Esta se encuentra ceñida a la cintura con un lazo, dejando al descubierto el pecho y el corazón deífico del Niño, siendo el forro de la misma de color rosado. Con este gesto se simboliza el ofrecimiento del amor divino y se derrama la divina providencia hacia el orante, puesto que ese es el significado del Sagrado Corazón ígneo. Así podemos citar a Rocío Millán: "Su corazón en llamas es la esencia de la providencia divina, el símbolo máximo de Jesús ungido, Jesús en su advocación de dador de dones, dador de esperanza, dador de amor, el «Yo Soy» místico de Jesús"23. Esta iconografía del Sagrado Corazón de Jesús Niño fue introducida en la escuela sevillana por el escultor Cristóbal Ramos, conociéndose en la Sevilla tardobarroca. Ramos la empleó en el Niño que forma parte del grupo de la Divina Pastora de la parroquia de la Inmaculada Concepción de Galaroza $(1797)^{24}$, siendo muy probable que fuese a raíz de un grabado del italiano Mannelli ${ }^{25}$. Efectivamente, en la obra de Ramos es una constante la representación del divino infante con esta particularidad, el corazón rodeado de llamas asomando en el torso. Ella aparece en otras representaciones como la del Niño Jesús junto a la Virgen de la Esperanza del convento de Santa Paula de Sevilla o la del San José, ya citado, de la capilla de la Santa Cruz del Rodeo. Entre las imágenes del Niño Jesús exento destacan por su similitud con las propuestas el Niño Jesús del monasterio de carmelitas descalzas de Sanlúcar la Mayor o el perteneciente a la colección particular de Carmen Torres $^{26}$. Finalmente en esta obra observamos una doble iconografía mezcla de las dos anteriores: el Divino Buen Pastor y el Sagrado Corazón de Jesús Niño. Jesús ofrece su Corazón en donación de amor con su mano izquierda y con la derecha porta el cayado pastoril, como Buen Pastor, sosteniendo sobre su hombro izquierdo a la oveja perdida. Así se trata la figura de Jesús Niño de una manera delicada y humana.

\section{DOS IMÁGENES DE NIÑO JESÚS DE VESTIR PORTADAS POR LA VIRGEN, UNA TERCERA PORTADA POR SAN JOSÉ Y UNA IMAGEN DE VESTIR EXENTA}

Posee igualmente el convento cuatro imágenes de terracota atribuibles al mismo autor pues siguen absolutamente sus rasgos estilísticos. De estas, dos son

\footnotetext{
${ }^{22}$ Montesinos Montesinos, 1986: 30-31.

${ }^{23}$ Millán, 2006: 473-474.

${ }^{24}$ González Gómez/Carrasco Terriza, 1981: 389.

25 Ardales, 1949: 411. Roda Peña, 1991: 345.

${ }^{26}$ Montesinos Montesinos, 1986: 40, 46-47, 51 y 69.
} 
imágenes de vestir de cuerpo completo con orificio en la parte posterior que permite la introducción de un perno para su acoplamiento a la imagen principal, en ambos casos de la Virgen. Una tercera es portada por un San José de pequeñas dimensiones. Este Niño Jesús se representa vestido con telas encoladas poseyendo un sistema de sujeción parecido al de las anteriores. Por último atribuimos una cuarta figura colocada sobre una peana de escaso mérito. Las imágenes que son portadas por la Virgen y San José son independientes con relación al autor de la talla principal. Las mismas pudieron ser introducidas con posterioridad para crear una nueva iconografía o bien para completarla en sustitución de otra imagen. La primera de ellas es portada por la talla en madera de la Virgen del Amparo y se encuentra en una hornacina del noviciado (Figura 5), la segunda se localiza en el retablo de la antesacristía de la iglesia monacal, formando parte del conjunto de candelero de otra talla en madera de la Virgen del Sagrado Corazón (Figura 6), mientras que la tercera es portada por un San José con rasgos roldanescos que se ubica en el coro bajo del cenobio (Figura 7). El primero de ellos tiene unas dimensiones de 20 centímetros de altura y representa al Divino Salvador pues porta en su mano izquierda el globo terráqueo rematado por la Cruz de la Redención en plata. Su mano derecha se encuentra en actitud de bendecir correspondiéndose con los rasgos de la demás obras. La segunda representa nuevamente la iconografía del Sagrado Corazón de Jesús Niño señalando con su mano izquierda un atributo en plata del corazón flameante de Cristo, mientras que con la derecha aparece, como el precedente, bendiciendo. Mide 25 centímetros de altura. El tercero de 12 centímetros de altura representa al divino infante acariciando con la mano derecha las barbas de su padre putativo. La mano izquierda reposa sobre su cadera. Este San José con claros rasgos roldanescos, al cual elaboraremos otro estudio, debió perder el Niño Jesús que portaba siendo sustituido por esta obra de telas encoladas en tonos rosáceos y verdosos de Ramos.

Por último, aportamos un Niño Jesús vestidero que se representa en actitud de bendecir adelantando ligeramente la pierna izquierda sobre la derecha (Figura 8). El autor lo representó con un paño de pureza que forma parte del modelado. Desgraciadamente los numerosos repintes de la obra nos impiden observar la calidad de la misma pero sus rasgos son indudablemente del citado autor. Sus dimensiones son de 27 centímetros de altura. Se coloca sobre una peana de escaso valor artístico que igualmente ha sido repintada. De nuevo observamos las facciones representativas del artista que las comparte a la perfección con las anteriores: rostro redondeado, con ojos de cristal, finas cejas arqueadas y pestañas levemente pinceladas. La nariz pequeña, así como la boca, esta vez cerrada, de labios finos y el esbozo de una dulce sonrisa. La tez nacarada con el característico hoyuelo. El minucioso modelado de su cabellera se arremolina en el centro de la frente, así como por encima de las orejas. No existe lugar a dudas de que se trata de cuatro imágenes del mismo autor. 
En relación a este tipo de representaciones vestideras encontramos principalmente un inconveniente a la hora de describir su iconografía. La problemática radica en la pérdida de su valor antropológico cuando pasan a ser piezas de museo u objetos de colección. Al ponerse exclusivamente en valor la calidad artística, en la mayoría de los casos son despojadas de sus ajuares perdiendo su verdadero carácter y "obviando su alto valor cultual y devocional". Estos elementos son los "que convierten a muchas de estas imágenes en piezas únicas, testimonios de una fe ampliamente vivida y sentida" 27 que serían desnaturalizadas al ser arrebatadas de su contexto. Estos Niños Jesús de vestir, así como el portado por San José guardan, igualmente, un notable parecido con esculturas documentadas y fechadas del mismo Ramos, así como con otras atribuidas a este pero de una semejanza patente. Observamos una clara similitud con las que portan la Virgen del Rosario, perteneciente a la hermandad de Pasión, o las de las dos vírgenes del Rosario que Ramos realizó en 1787 para la hermandad del Rosario del sevillano convento de San Pablo ${ }^{28}$. Del mismo modo, es patente la semejanza con las obras del Niño Jesús con San Cayetano y la Virgen de los Desamparados y los ángeles que la elevan, datado en torno a 1774 y perteneciente a la iglesia de Santa Catalina ${ }^{29}$, al igual que el mismo grupo de la localidad de El Saucejo ${ }^{30}$ o el Niño portado por el San José de la Caridad de $1782^{31}$.

\section{CONCLUSIÓN}

A pesar de no contar con la correspondiente documentación que acredite la autoría de las obras, razones estéticas, estilísticas, iconográficas y técnicas en comparación con la producción documentada del autor, nos permiten adscribir, con poco margen para el error, la hechura del conjunto de estas obras a la mano del escultor Cristóbal Ramos Tello. Las obras que aquí presentamos responden a una temática religiosa de escultura andaluza que fue tratada frecuentemente por Ramos, creando unos modelos que tuvieron gran éxito pues los repitió en diversas ocasiones y con escasas variaciones.

Con este estudio creemos que hemos contribuido a aumentar y dar a conocer el catálogo de las obras escultóricas de este gran artista, si bien como ya hacíamos alusión durante el desarrollo del mismo, sobre al menos una de dichas esculturas ya se tenían referencias fotográficas de la misma. Sin embargo, faltaba un trabajo de unificación en torno al monasterio como elemento aglutinador de estas,

\footnotetext{
27 Peña Martín, 2011: 43.

28 Ros González, 2001: 34-36.

29 Montesinos Montesinos, 1986: 49. Gómez Piñol, 2008: 71.

30 Santos Márquez, 2008: 115-120.

31 Montesinos Montesinos, 1986: 46-47.
} 
así como su publicidad y catalogación siguiendo las recomendaciones internacionales para la preservación de las obras de arte.

Fecha de recepción: 1 de julio de 2019

Fecha de aceptación: 5 de junio de 2020

\section{BIBLIOGRAFÍA}

Arana de Varflora, Fermín (1789): Compendio histórico descriptivo de la muy noble y muy leal ciudad de Sevilla. Sevilla: Oficina de Vázquez, Hidalgo y Compañía.

Arbeteta Mira, Letizia (1996): Vida y Arte en las clausuras madrileñas. El ciclo de la Navidad. Madrid: Museo Municipal de Madrid.

Arbeteta Mira, Letizia/Fernández Collado, Ángel (2002): Navidad Oculta. Los Niños Jesús de las clausuras toledanas. Toledo: Antonio Pareja Editor.

(2003): Navidad oculta II. Los Niños Jesús de las clausuras toledanas. Toledo: Antonio Pareja Editor.

Bartolomé García, Fernando R. (2015): "Imágenes exentas de divinos infantes en Álava”. En: Sancho el sabio: Revista de cultura e investigación vasca, 38, pp. 197-218.

De Ardales, Juan Bautista (1949): La Divina Pastora y el beato Diego José de Cádiz. Sevilla: Imprenta de la Divina Pastora.

De Madrazo, Pedro (1884): España. Sus monumentos y artes. Su naturaleza e historia. Sevilla y Cádiz. Barcelona: Establecimiento Tipográfico-Editorial de Daniel Cortezo y compañía.

Díaz Martín, Luis Vicente (1995): Pedro I. 1350-1369. Palencia: Diputación Provincial de Palencia.

Dobado Fernández, Juan (2010): La Navidad en Clausura. Imágenes del Niño Jesús en el Carmelo. Córdoba: Comisión de Coronación de Nuestra Señora del Carmen del Convento de San José (San Cayetano).

Gestoso y Pérez, José (1889): Sevilla monumental y artística. Sevilla: Oficina tipográfica de El Conservador.

Gómez Piñol, Emilio et al. (2008): La iglesia de San Román: historia y proceso de restauración. Sevilla: Emasesa Metropolitana.

González de León, Félix (1839): Noticia histórica del origen de los nombres de las calles de Sevilla. Sevilla: José Morales.

(1844): Noticia histórica, artística y curiosa de todos los edificios públicos, sagrados y profanos de de esta Muy Noble, Muy Leal, Muy Heroica e Invicta Ciudad de Sevilla, y de muchas casas particulares. Sevilla: Imprenta de José Hidalgo.

González Gómez, Juan Miguel/Carrasco Terriza, Manuel (1981): Escultura mariana onubense. Huelva: Instituto de Estudios Onubenses "Padre Marchena”. 
González González, Julio (1986): Reinado y diplomas de Fernando III. Córdoba: Caja de Ahorros y Monte de Piedad de Córdoba.

González Jiménez, Manuel (2006): Fernando III el Santo. Sevilla: Fundación José Manuel Lara.

Guijo Pérez, Salvador (2017): "Relación y formación del patrimonio urbano del monasterio de San Leandro de Sevilla. Siglos XIII-XVI". En: Estudios sobre Patrimonio, Cultura y Ciencias Medievales, 19, pp. 609-634.

(2018a): "Orígenes del Monasterio de San Leandro y su fusión con el emparedamiento de San Pedro de Sevilla. Siglos XIII-XVI". En: Historia. Instituciones. Documentos, 45, pp. 157-186.

(2018b): "Sobre la contratación de retablos para la nueva iglesia del monasterio de San Leandro de Sevilla. Finales del siglo XVI y primera mitad del siglo XVII”. En: Archivo Hispalense, 306-308, pp. 91-117.

- (2019a): "El convento de San Leandro de Sevilla promotor de la devoción al Sagrado Corazón de Jesús en la ciudad". En: Boletín de las Cofradias de Sevilla, 725, pp. 496-499.

(2019b): "La sustitución del retablo mayor del monasterio de San Leandro de Sevilla y su promotora Doña Teresa de Anguiano y Cárdenas”. En: Laboratorio de Arte, 31, 2019, pp. 671-682.

Llompart i Moragues, Gabriel (1980): "Imágenes mallorquinas exentas del Niño Jesús". En: Boletín del Seminario de Estudios de Arte y Arqueología de la Universidad de Valladolid, 46, pp. 363-374.

Llordén, Andrés (1973): Convento de San Leandro de Sevilla (Notas y documentos para su historia). Málaga: Imprenta Provincial de Málaga.

Martínez Díez, Gonzalo (1993): Fernando III. 1217-1252. Palencia: La Olmeda.

Martínez Lara, Pedro Manuel/De la Torre Amerighi, Iván (2017): "Una escultura desconocida de Cristóbal Ramos (1725-1799). Iconografía, uso artístico y mentalidad ilustrada a propósito de una imagen de San José con Niño”. En: Liño, 23, pp. 57-68.

Millán, Rocío S. (2006): "Historia, iconografía e iconología del Sagrado Corazón de Jesús". En: Boletín de las Cofradías de Sevilla, 569, pp. 473-474.

Miura Andrades, José María (1999): Frailes, monjas y conventos: las Órdenes Mendicantes y la sociedad sevillana bajomedieval. Sevilla: Diputación Provincial de Sevilla.

Montesinos Montesinos, Carmen (1986): El escultor sevillano D. Cristóbal Ramos (1725-1799). Sevilla: Diputación Provincial de Sevilla.

Ortiz de Zúñiga, Diego (1796): Anales Eclesiásticos y Seculares de la Muy Noble y Muy Leal, Ciudad de Sevilla. Madrid: Imprenta Real.

Peña Martín, Ángel (2009): "No ai cossa qve mas despierte que dormir sobre la muerte. En torno a la imagen del Niño Jesús dormido sobre la cruz del convento del Corpus Christi de Valladolid”. En: ¡Aleluya! Revista de la Asociación Belenistas de Valladolid, 4, pp. 28-31. 
(2010): "El verme así no te asombre. El Niño Jesús Soberano del Monasterio de Comendadoras de San Juan de Jerusalén de Zamora". En: Arte y patrimonio de las órdenes militares de Jerusalén en España: hacia un estado de la cuestión, Madrid: Consejo Superior de Investigaciones Científicas, pp. 113-128.

(2011): "El peregrino del cielo la devoción al Niño Jesús peregrino en las clausuras". En: Campos y Fernández de Sevilla, Francisco Javier (coord.): La clausura femenina en el Mundo Hispánico: una fidelidad secular. San Lorenzo del Escorial: Real Centro Universitario Escorial-María Cristina, vol. 1, pp. 31-48.

Pérez López, Nerea Virginia (2017): "La iconografía del Buen Pastor Niño y su vinculación con la pintura barroca sevillana”. En: Laboratorio de Arte, 29, pp. 311-328

Reyes de la Carrera, Manuel Ramón (2014): "Un niño Jesús de Cristóbal Ramos y un calvario genovés en Trigueros". En: Cuadernos de Estepa, 4, pp. 215223.

Roda Peña, José (1991): "Un niño Jesús del escultor Gabriel de Astorga". En: Laboratorio de Arte, 4, pp. 341-346.

Ros González, Francisco S. (2001): "Dos imágenes de Cristóbal Ramos para la Hermandad del Rosario de San Pablo". En: Boletín de las Cofradías de Sevilla, 509, pp. 34-36.

Santos Márquez, Antonio Joaquín (2008): Patrimonio histórico-artístico de El Saucejo. Sevilla: Diputación de Sevilla. 


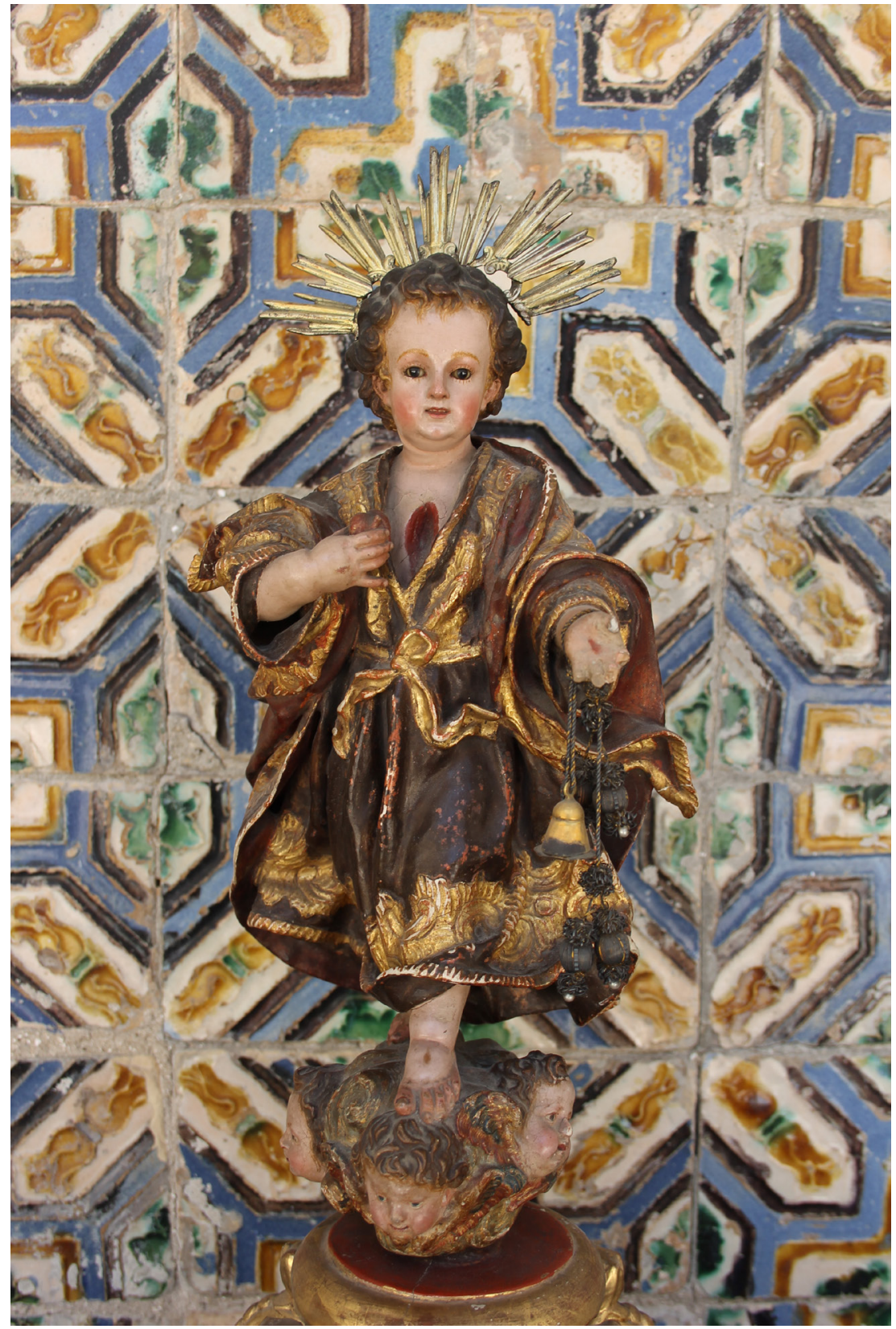

Figura 1. Cristóbal Ramos Tello, El Sagrado Corazón de Jesús Niño, “Expósito o Esposito”, monasterio de San Leandro, Sevilla. Foto: Salvador Guijo Pérez. 


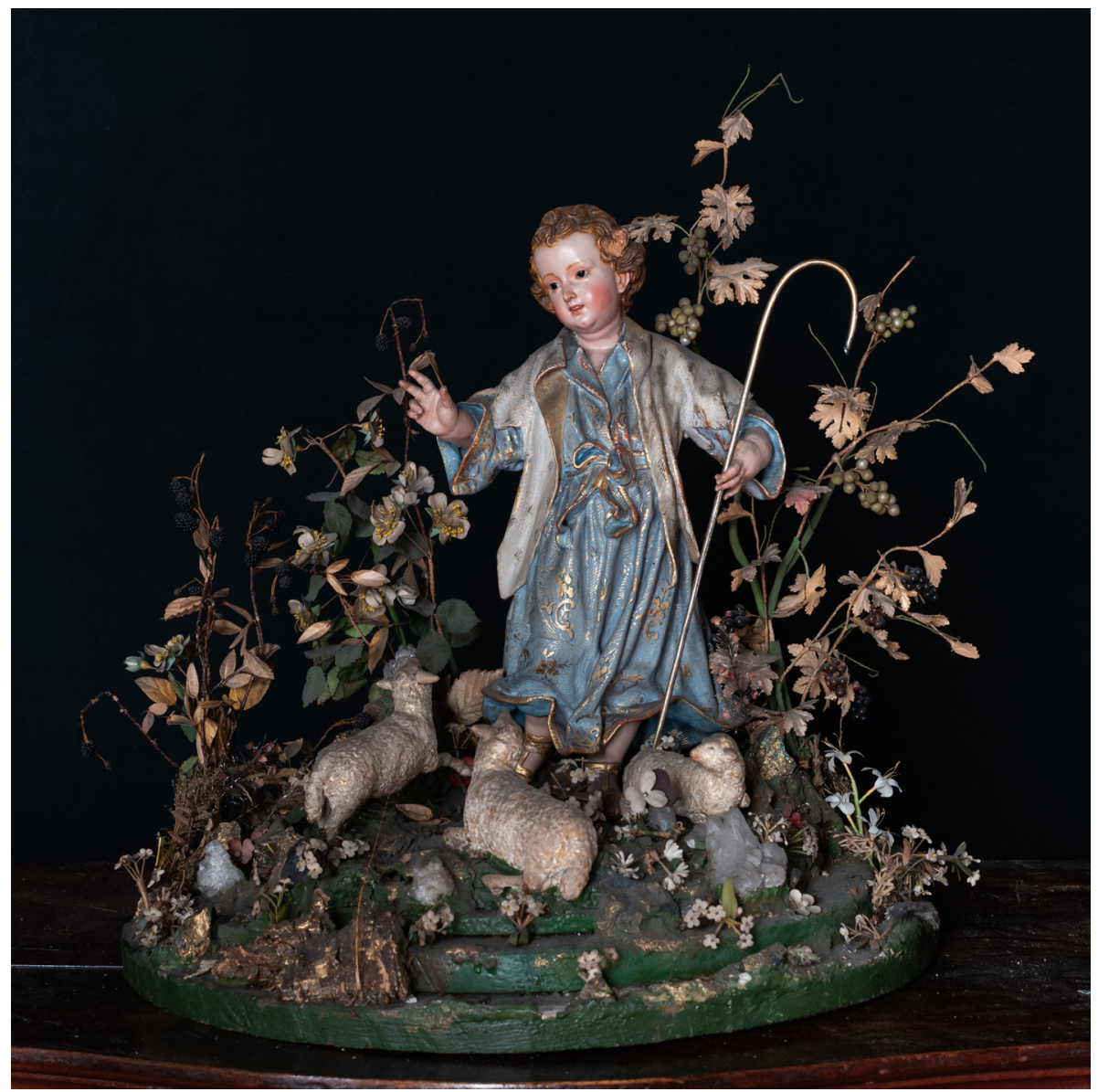

Figura 2. Cristóbal Ramos Tello, El Buen Pastor Niño o "Pastorcito", monasterio de San Leandro, Sevilla. Foto: Daniel Salvador-Almeida. 


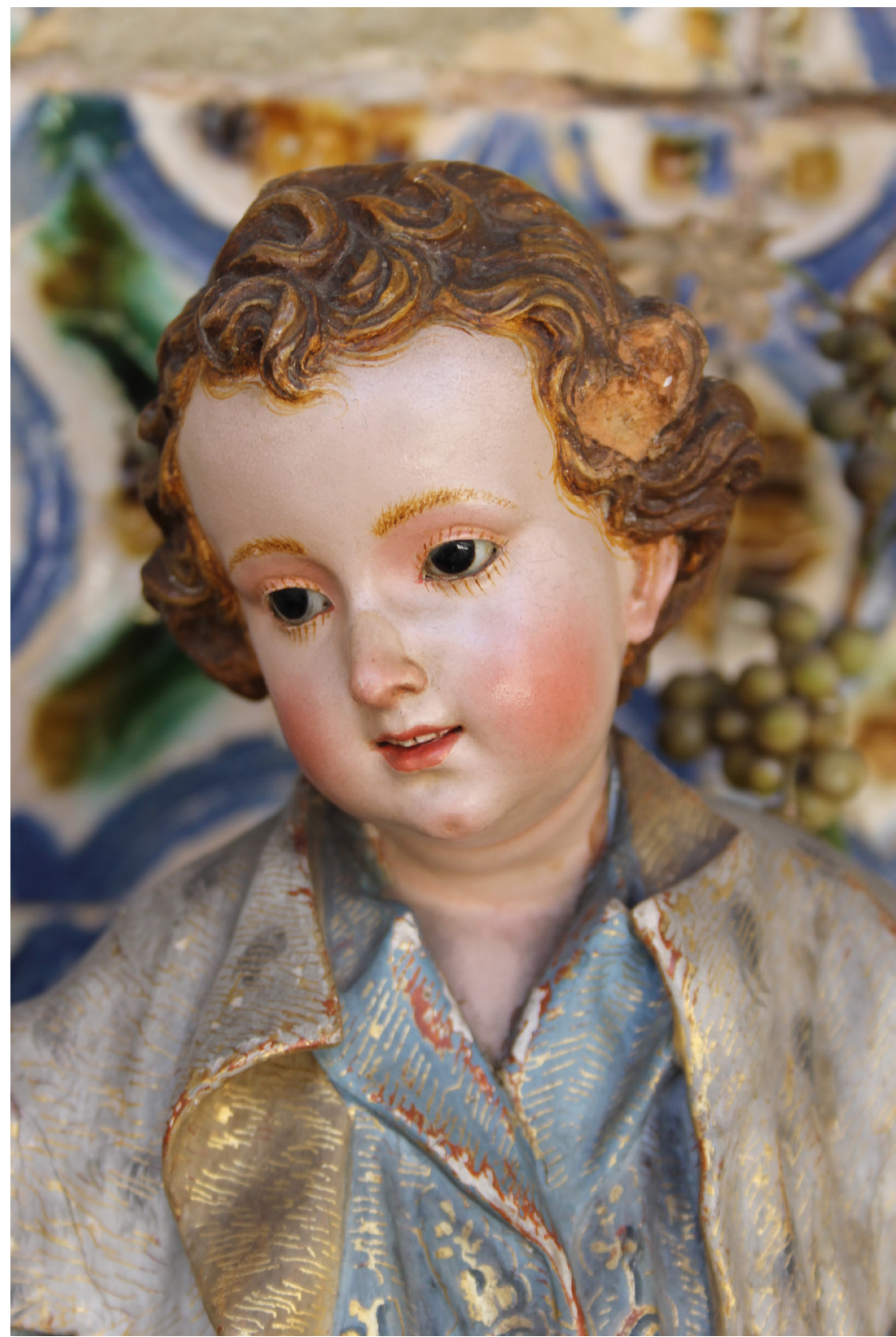

Figura 3. Cristóbal Ramos Tello, El Buen Pastor Niño o "Pastorcito", monasterio de San Leandro, Sevilla. Foto: Salvador Guijo Pérez. 


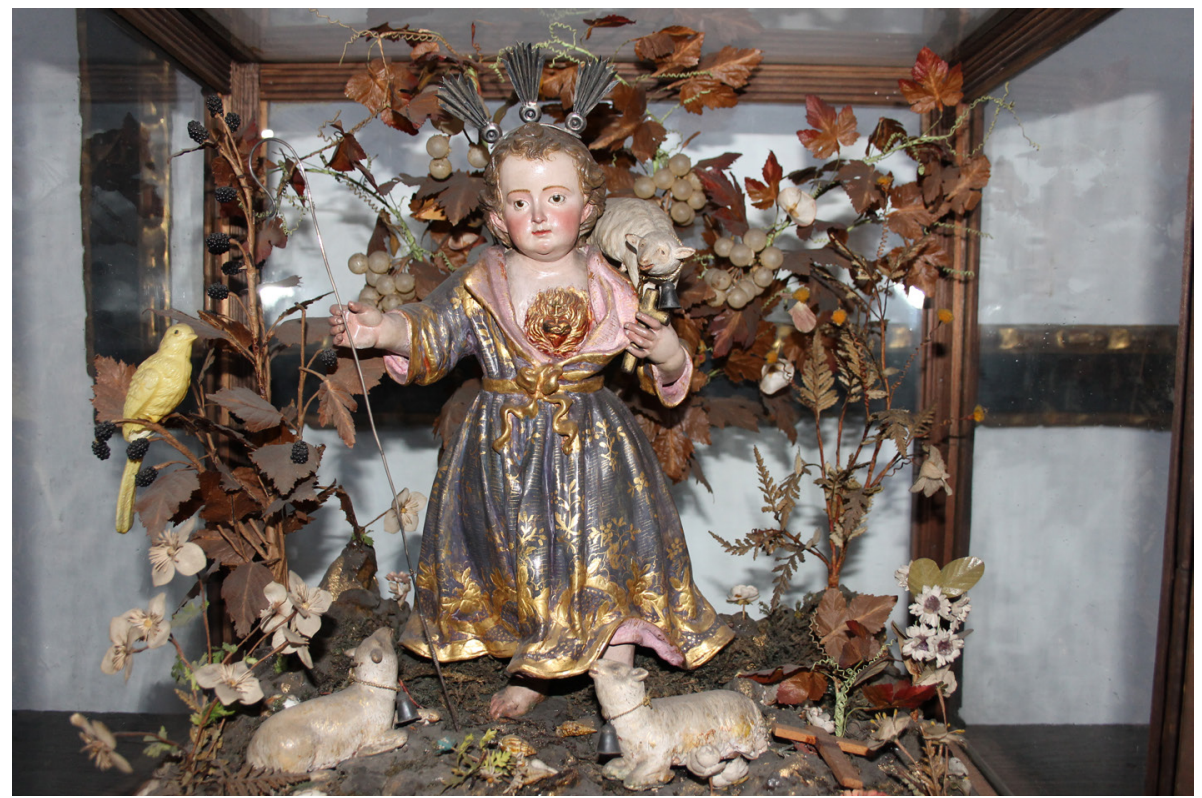

Figura 4. Cristóbal Ramos Tello, El Buen Pastor del Sagrado Corazón de Jesús Niño o "Divino Pastor", monasterio de San Leandro, Sevilla. Foto: Salvador Guijo Pérez. 


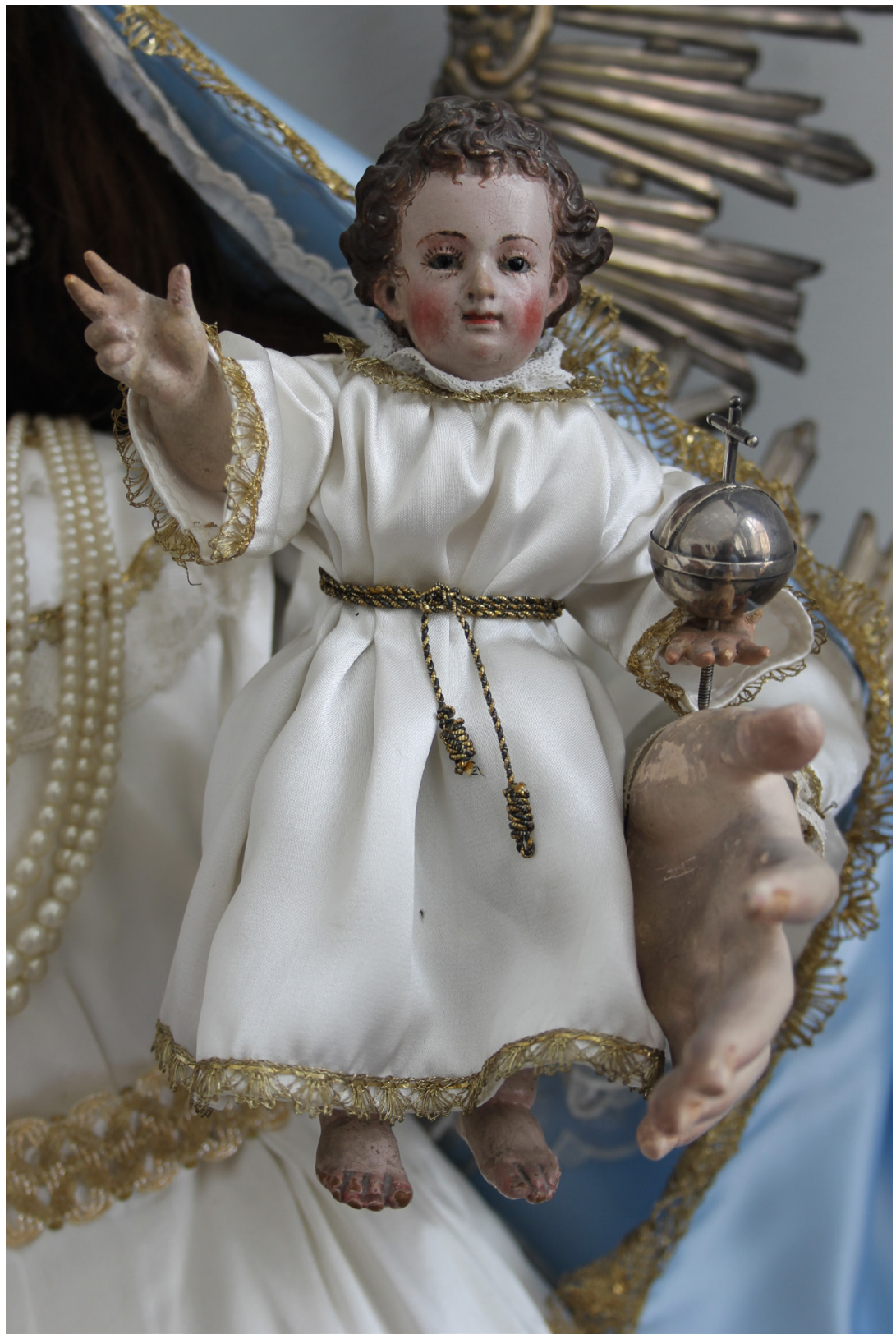

Figura 5. Cristóbal Ramos Tello, Niño Jesús (Virgen del Amparo), monasterio de San Leandro, Sevilla. Foto: Salvador Guijo Pérez. 


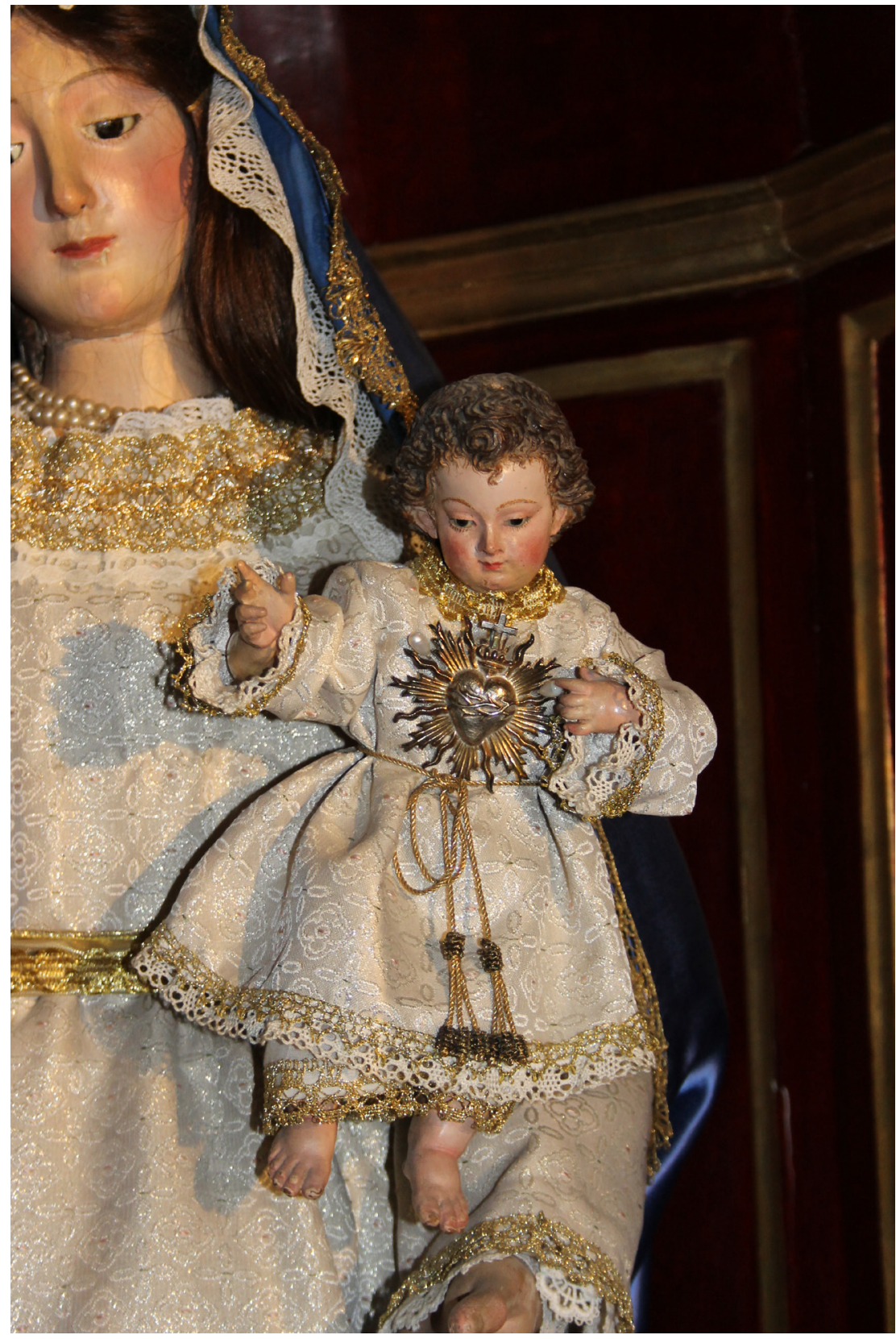

Figura 6. Cristóbal Ramos Tello, Sagrado Corazón de Jesús Niño (Virgen del Sagrado Corazón), monasterio de San Leandro, Sevilla. Foto: Salvador Guijo Pérez. 


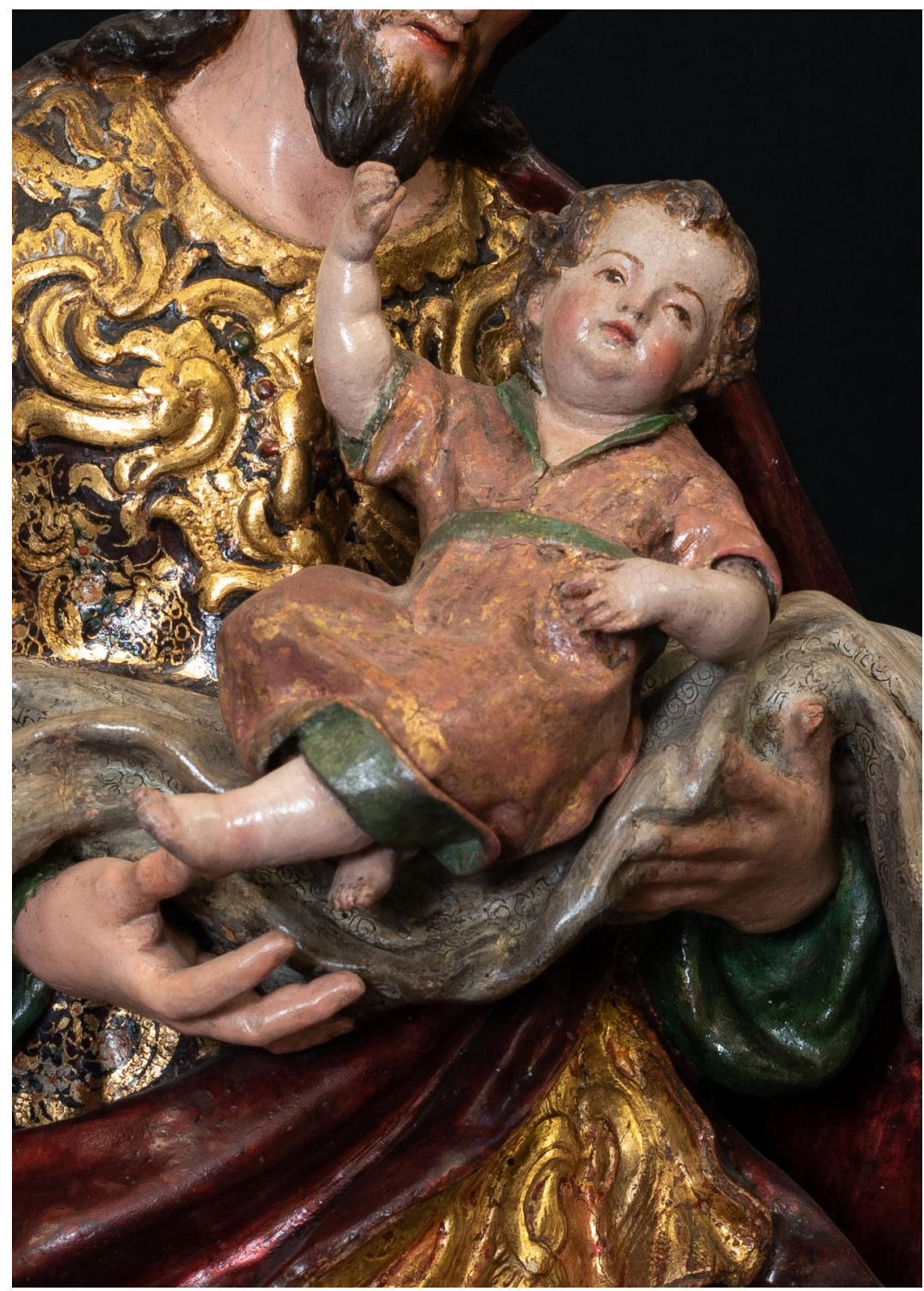

Figura 7. Cristóbal Ramos Tello, Niño Jesús (San José), monasterio de San Leandro, Sevilla. Foto: Daniel Salvador-Almeida. 


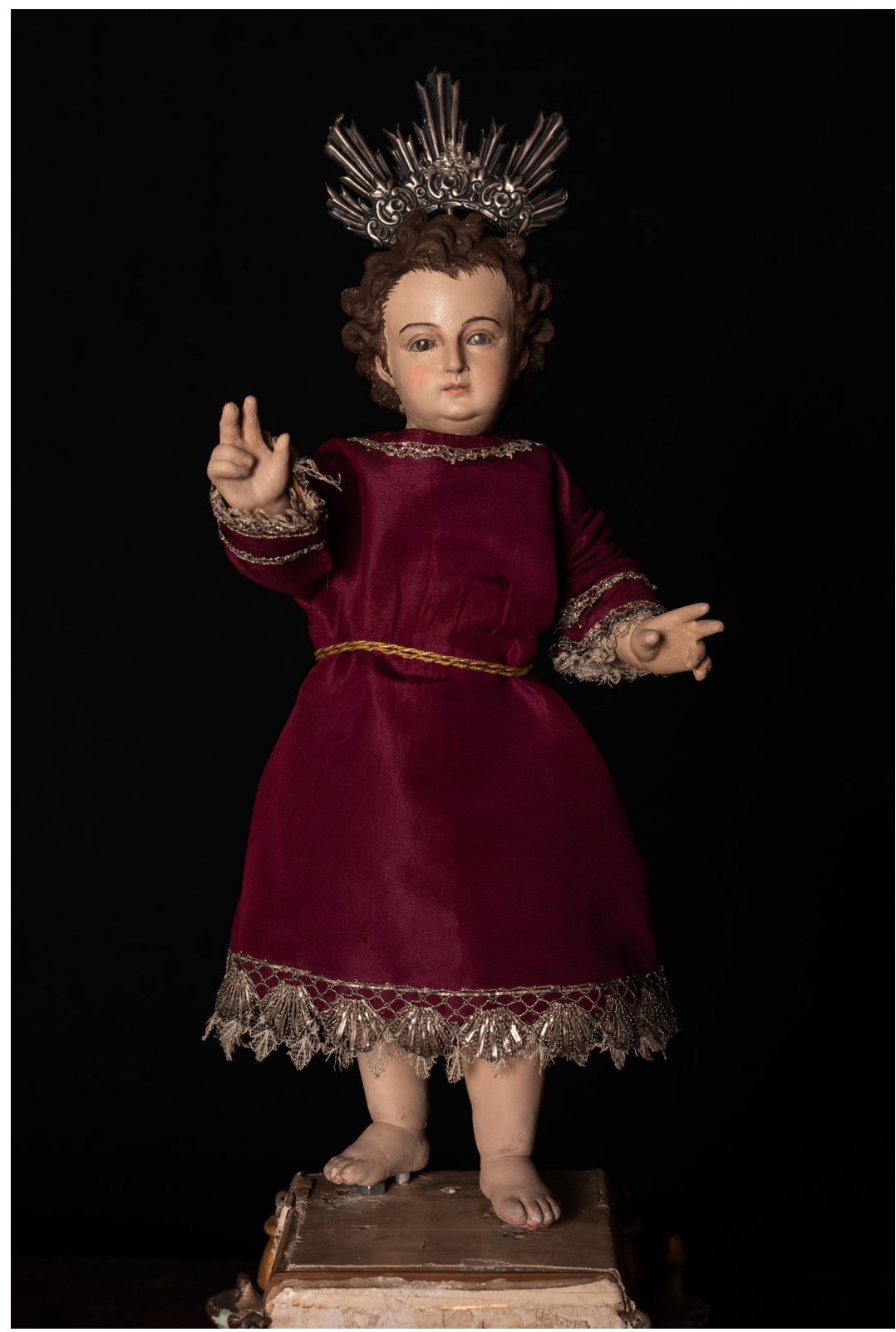

Figura 8. Cristóbal Ramos Tello, Niño Jesús, monasterio de San Leandro, Sevilla. Foto: Daniel Salvador-Almeida. 